\title{
Screening and Interactive Effects of Soil Microbial Enzymes Activities of Diazotrophic PGPR
}

\author{
Rasinja Englengpi*, Rajen Baruah and Amrita Phukan \\ Soil Microbiology Laboratory, Research Scholar, Department of Soil Science, Assam \\ Agricultural University-Jorhat, Assam, India \\ *Corresponding author
}

\section{A B S T R A C T}

Diverse communities of beneficial plant growth promoting diazotrophs harbour in Rice rhizosphere which mostly plays a significant role in supplementing Biofertilizer, bioprotectant and bio stimulator and improves the crop productivity directly or indirectly. 53 rhizobacterial were isolated from lowland rice rhizosphere of Jorhat district of Assam in non-selective TSA media. 30 pure culture

\begin{tabular}{|c|c|}
\hline $\begin{array}{l}\text { Brinjal (Solanum } \\
\text { melongena), } \\
\text { Azospirillum }\end{array}$ & $\begin{array}{l}\text { Azospirillum, one Azotobacter and one Pseudomonas for screening multiple PGP traits both } \\
\text { qualitative and quantitatively. All the selected cultures produced ammonia but Proteolytic activity } \\
\text { was limited to few cultures. The test cultures enhanced seed germination ranging from } 60-100 \% \text {, } \\
\text { IAA production from } 15.8 \text { to } 22.6 \mathrm{mg} \mathrm{l}^{-1} \text { and P-solubilization from } 0.3-3.1 \text { percent. The results also } \\
\text { indicated direct relationship of drop in } \mathrm{pH}(6.57 \text { to } 4.01) \text { to extent of P-solubilized with days of }\end{array}$ \\
\hline Article Info & $\begin{array}{l}\text { incubation. A Pot culture experiment was conducted during November, } 2016 \text { to evaluate } 7 \text { screened } \\
\text { cultures of PGP on growth characters of brinjal (Solanum melongena) and post-harvest parameters. }\end{array}$ \\
\hline $\begin{array}{l}\text { Accepted: } \\
\text { 04 July } 2019 \\
\text { Available Online: } \\
10 \text { August } 2019\end{array}$ & $\begin{array}{l}\text { Among the test PGPR, culture P } 20 \text { (Azospirillium) recorded significantly highest percent increase in } \\
\text { root length }(21.6 \%) \text {, plant height }(40.6 \%) \text {, root dry weight }(120.6 \%) \text {, shoot dry weight }(84.82 \%) \text {, } \\
\text { total biomass }(86.86 \%) \text {, root shoot ratio }(19.45 \%) \text {, number of leaves }(144.4 \%) \text { and number of } \\
\text { branches }(200 \%) \text { over uninoculated control. On post-harvest parameters, the microbial population }\end{array}$ \\
\hline & $\begin{array}{l}\mu \mathrm{g} \text { TPF } \mathrm{g}^{-1} \text {, hydrolysis of Fluorescein diacetate ranged from } 64.1 \text { to } 80.4 \mu \mathrm{g} \text { FDA g } \mathrm{hr}^{-1} \mathrm{hr}^{-1} \text { and } \\
\text { phosphomonoesterase activity ranged from } 75.0 \text { to } 94.2 \mu \mathrm{g} \text {-nitrophenol g } \mathrm{g}^{-1} \mathrm{~h}^{-1} \text {. Azospirillium (P } \\
\text { 20) and Phosphate Solubilizing Bacteria (P 49) suggest to be the most efficient biofertilizers, } \\
\text { biopesticide and biostimulator properties. }\end{array}$ \\
\hline
\end{tabular}

\section{Introduction}

The rhizosphere is a thin layer of soil which immediately surrounds the plant roots and is the active sites for root activity and microbial proliferation. This zone is rich in nutrients when compared with the bulk soil due to the accumulation of a variety of plant exudates, such as amino acids and sugars, providing a niche area for energy and nutrients source for bacteria. Plant Growth Promoting Rhizobacteria (PGPR) or naturally occurring soil bacteria that aggressively colonize plant roots and accelerate plant growth and 
development via direct and indirect mechanism on interaction with the crop by improving productivity and immunity. Plant Growth Promoting Rhizobacteria that fix atmospheric nitrogen by reducing dinitrogen to ammonia or simply $\mathrm{N}_{2}$ fixers are called 'diazotrophs'. PGPR on inoculation to the crop can directly synthesize phytohormones (IAA) or facilitate the uptake of nutrients and improve soil fertility and indirectly prevent some of the phytopathogens through various mechanisms by producing siderophore, antibiotics, HCN for disease resistance, antimetabolite to avoid predation and competition, $\beta-1,3$, glucanase, chitinase, (Kennedy et al., 2004). Depending on their activity and abundance on the soil environment some of the PGPR in rice rhizosphere are: Azoarcus, Azospirillum, Bacillus, Burkholderia, Herbaspirillum, Klebsiella and many other beneficial microbes (Ritu et al., 2017; Hassan et al., 2017). To screen diazotrophic PGP traits and interactive nature of soil microbial enzyme, the present study was undertaken and isolate from rice rhizosphere.

\section{Materials and Methods}

The investigation was carried out during 20152017, in the department of Soil Science, Assam Agricultural University; Jorhat. 5-10 $\mathrm{cm}$ rice rhizospheric soils with the roots were collected randomly from 20 different lowland rice fields under Jorhat district of Assam and isolated the rhizobacteria through serial dilution spread plate technique (Somasegaren and Hoben, 1994) using non selective TSA (Tryptic Soy Agar) media. Diazotrophic PGPR such as P-solubilizer was isolated using Pikovskaya's medium, Azospirillum on semi solid NFB (Nitrogen free bromothymol blue) medium, Azotobacter on Jensen medium and Psuedomonas on the King's B medium. Altogether 10 PGPR were selected as 5 phosphate solubilizers (P 45, P 49, P 50, P 51 and P 53), 3 Azospirillium (P 03, P 20, P 28), 1 Azotobacter (P 27) and 1 Pseudomonas $(\mathrm{P}$ 44).

\section{Proteolytic activity}

Proteolytic activity was tested using skimmed milk agar medium (Kumar et al., 2005). The selected isolates inoculated into the cut well skim milk agar plates, observed the clear zone around the colonies indicated positive proteolytic activity and recorded the diameter of clear zone in $\mathrm{mm}$.

\section{Phosphate solubilization (Incubation study)}

The quantitative estimation of P-solubilization by bacterial isolates was assessed by the vanadomolybdophosphoric yellow color method (Jackson, 1973). The cultures were grown in 50-100 $\mathrm{ml}$ aliquots of pikovskaya broth medium containing $0.5 \%$ Tricalcium phosphate and incubated upto 30 days in batch at $28 \pm 2^{\circ} \mathrm{C}$. Centrifuged at $10,000 \mathrm{rpm}$ for 10 15 minutes. $2.5 \mathrm{ml}$ bartons reagent was added $10 \mathrm{ml}$ aliquot and made to final volume $50 \mathrm{ml}$. The intensity of yellow color was read in a colorimeter at $430 \mathrm{~nm}$ wavelength. Samples were drawn at $0,7,15$ and 30 days interval to assess soluble phosphorus content with days of incubation. The values were calibrated with the standard curve prepared from known concentration of $\mathrm{KH}_{2} \mathrm{PO}_{4}$. Phosphate solubilizing activity was expressed as percent $\mathrm{P}$ released from TCP also the $\mathrm{pH}$ of the growth medium was determined at $0,7,15$ and 30 days.

\section{IAA Production}

IAA production by the diazotrophic rhizobacterial isolates was estimated by the method described by Wohler (1997). The rhizobacterial isolates were grown in the Luria-Bertani agar medium (LB) for $72 \mathrm{hrs}$ and centrifuged at $7000 \mathrm{rpm}$ for $5 \mathrm{~min}$. 
Removed the supernatant and add $3 \mathrm{ml}$ of phosphate buffer of $\mathrm{pH} 7.5$ along with $1.0 \%$ glucose and $1.0 \%$ tryptophan into the bacterial pellets and incubated for $24 \mathrm{hrs}$ at $37^{\circ} \mathrm{C} .2 \mathrm{ml}$ of $5 \%$ trichloro acetic acid and $1 \mathrm{ml}$ of $0.5 \mathrm{M}$ $\mathrm{CaCl}_{2}$ were added. Thereafter, the solution was filtered by whatman no. 2 filter paper. Each $3 \mathrm{ml}$ filtrates was taken and added $2 \mathrm{ml}$ of Salper's solution ( $2 \mathrm{ml}$ of $0.5 \mathrm{M} \mathrm{FeCl}_{3}$ and $98 \mathrm{ml}$ of $35 \%$ perchloric acid). Incubated for 30 minutes at $25^{\circ} \mathrm{C}$ in dark until pink color developed. The intensity of pink color developed was measured using UV-VIS spectrophotometer at $535 \mathrm{~nm}$ wavelength. The quantities of IAA produced were calculated from the standard curve prepared from the known concentration of IAA and expressed as $\mathrm{mg} \mathrm{^{-1 }}$.

\section{Germination properties}

The bacteria-plant association released significant amounts of necessary phytostimulator and nutrients from the substrate and help seed germination and establishment. Effect of PGPR on seed germination was performed by semi solid water agar medium. The healthy seeds of wheat, rice and maize were selected, soaked and surface sterilized with $0.1 \%$ acidified $\mathrm{HgCl}_{2}$ for 5 mins. After sterilization, the seeds were further washed with series of sterile water to remove the traces of $\mathrm{HgCl}_{2}$. Five seeds of each crop in triplicate were placed onto the semi-solid water agar plates, kept at ambient condition for 30 minutes and thereafter incubated at $30 \pm 1^{\circ} \mathrm{C}$ for $18-48 \mathrm{hrs}$. The appearance of radical and calculated germination percentage over control using the following formula (Ashrafuzzaman et al., 2009).

Germination percentage $(\%)=\frac{\text { Number of seeds germinated }}{\text { Total number of seeds }} \times 100$

After PGP activities were screened out both qualitative and quantitative, efficient Diazotrophic PGPR were inoculated on Brinjal (Solanum melongena), with variety PPL (long) for determining survivability and endophytic colonizing ability of inoculated isolates with the crop on soil. The experiment was conducted during November, 2016 at Biofertilizer unit, Department of Soil Science, Assam Agricultural University, Jorhat. A total of 9 treatment combinations were replicated thrice were selected as Treatment details: $\mathrm{T}_{1}$ Absolute control: $6 \mathrm{~g}$ soil; $\mathrm{T}_{2}$ Reference control: $6 \mathrm{~g}$ soil $+30 \mathrm{~g}$ compost + recommended dose of NPK at 50:50:50; $\mathrm{T}_{3}$ : $6 \mathrm{~g}$ soil $+30 \mathrm{~g}$ compost $+\mathrm{P} 51(\mathrm{PSB}) ; \mathrm{T}_{4}: 6 \mathrm{~g}$ soil $+30 \mathrm{~g}$ compost $+\mathrm{P} 50(\mathrm{PSB}) ; \mathrm{T}_{5}: 6 \mathrm{~g}$ soil + $30 \mathrm{~g}$ compost $+\mathrm{P} 49(\mathrm{PSB}) ; \mathrm{T}_{6}: 6 \mathrm{~g}$ soil $+30 \mathrm{~g}$ compost + P 03 (Azospirillium); $\mathrm{T}_{7}: 6 \mathrm{~g}$ soil + $30 \mathrm{~g}$ compost $+\mathrm{P} 20$ (Azospirillium); $\mathrm{T}_{8}: 6 \mathrm{~g}$ soil $+30 \mathrm{~g}$ compost $+\mathrm{P} 27$ (Azotobacter) and $\mathrm{T}_{9}$ : $6 \mathrm{~g}$ soil $+30 \mathrm{~g}$ compost $+\mathrm{P} 44$ (Psuedomonas). $20 \mathrm{ml}$ inoculum pot $^{-1}$ of active log phase i.e. $10^{8} \mathrm{cfu} \mathrm{ml}^{-1}$ were inoculated in 2 splits first 10 $\mathrm{ml}$ at 7 days after transplanting and the second inoculation of $10 \mathrm{ml}$ was done 15 days after transplanting. The crop was raised for 60 days up to flowering stage and the growth parameter.

\section{Post-harvest parameter in soil}

Population dynamics of total bacteria, PSB, Azospirillium, Azotobacter and Pseudomonas in soil after harvest

The enumeration of total population dynamicswas performed by the method described by Vincent (1970) using spread plate serial dilution technique in appropriate growth medium. The inoculated PSB, Azospirillium, Azotobacter and Psuedomonas cultures were serially diluted and plated in their respective media such as Pikovskaya's, $\mathrm{NFb}$, Jenson and King's B respectively. The CFU of individual bacterial count was made following the formula as described by Sakthi 
et al., (2013).

$\mathrm{Cfu} \mathrm{ml}^{-1}=\frac{\text { No. of colonies } \times \text { reciprocal of dilution used }}{\text { Volume of aliquot taken }} \times 100$

\section{Dehydrogenase enzyme assay}

The quantitative estimation of Dehydrogenase enzyme was performed by the TTC method described by Thalman (1968). $5 \mathrm{~g}$ of each soil sample was weighed in $100 \mathrm{ml}$ conical flask and mixed with $5 \mathrm{ml}$ TTC solution, sealed with rubber stopper and incubated for $24 \mathrm{hrs}$ at $30 \pm 1^{\circ} \mathrm{C}$. The control contained only $5 \mathrm{ml}$ of $100 \mathrm{mM}$ Tris buffer without TTC. Added 40 $\mathrm{ml}$ acetone to each flask, shacked thoroughly and incubated at room temperature for $2 \mathrm{hrs}$ in the dark (shaking the flask at intervals). The absorbance of the resultant colour (Red) read at $546 \mathrm{~nm}$ wavelength using UV-VIS spectrophotometer. The quantities of Dehydrogenase enzyme in the extract calculated from the standard curve prepared with the known concentration of TPF and expressed the quantity of DHA in $\mu \mathrm{g}$ TPF $\mathrm{g}^{-1}$ using the formula:

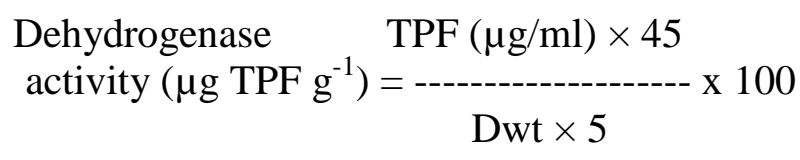

Where, Dwt is dry weight of $1 \mathrm{~g}$ moist soil, 5 is the moist soil used ( $\mathrm{g}$ ), and 45 is the volume of solution added to the soil sample in the assay

\section{Hydrolysis of Fluorescein Diacetate}

The quantitative estimation of hydrolysis of Fluorescein Diacetate enzyme was performed by the method described by Schnurer and Rosswall (1982). $1 \mathrm{~g}$ of each of soil sample was suspended in sterile culture tube and added $7.5 \mathrm{ml}$ of potassium phosphate buffer (60 mM, pH 7.6) and allowed to equilibrate at $25^{\circ} \mathrm{C}$ on shaker. After shaking, $0.1 \mathrm{ml}$ FDA solution (1000 $\mu \mathrm{g} / \mathrm{ml})$ was added, again shaked in the shaker and further incubated at $25^{\circ} \mathrm{C}$ for 30 minutes. For blank, $0.1 \mathrm{ml}$ acetone was added instead of $0.1 \mathrm{ml}$ FDA and incubated for $30 \mathrm{~min}$. After incubation, $7.5 \mathrm{ml}$ of extractant (chloroform: methanol; 2:1) was added to both the sample and blank to stop the reaction. The lid was replaced and mixed the content thoroughly in vortex for $10 \mathrm{sec}$. Thereafter centrifuged the mixture at low speed $(\mathrm{RCF}=300 \times \mathrm{g}$ for $2 \mathrm{~min})$ and transferred $1.2 \mathrm{ml}$ upper phase to 1.5 centrifuge tube and again centrifuged at $(\mathrm{RCP}=16,500 \times \mathrm{G}$ for 5 $\mathrm{min})$ to remove suspended particles. One $\mathrm{ml}$ of supernatant was taken in the cuvette and measured OD at $490 \mathrm{~nm}$ on spectrophotometer against blank. The quantity of Fluorescein was calculated from the standard curve prepared with the known concentration of fluorescein and expressed in $\mu \mathrm{g}$ FDA $\mathrm{g}^{-1} \mathrm{hr}^{-1}$ as follows:

Fluorescein

FDA $(\mu \mathrm{g} / \mathrm{ml}) \times 15$

Diacetate, $\left(\mu \mathrm{g} \mathrm{FDA} \mathrm{g}^{-1} \mathrm{hr}^{-1}\right)=$

Dwt $\times 1$

Where, dwt is dry weight of $1 \mathrm{~g}$ moist soil, 1 is the moist soil used (g), and 15 is the volume of the solution added to the soil sample in the assay.

\section{Phosphomonoesterase}

The quantitative estimation of Phosphomonoesterase enzyme was performed by the method described by Tabatabai and Bremner (1969). $1 \mathrm{~g}$ of each of soil sample was weighed in $50 \mathrm{ml}$ conical flask and added $4 \mathrm{ml}$ MUB along with $0.25 \mathrm{ml}$ toluene and 1 $\mathrm{ml}$ of $115 \mathrm{mM}$ p-nitrophenyl phosphate solution. The content was swirled and incubated at $37^{\circ} \mathrm{C}$ for $1 \mathrm{hr}$. After incubation, 1 $\mathrm{ml}$ of $0.5 \mathrm{M} \mathrm{CaCl}_{2}$ and $4 \mathrm{ml}$ of $0.5 \mathrm{M} \mathrm{NaOH}$ was added and mixed thoroughly. After filtration, the yellow color filtrate determined the absorbance at $400 \mathrm{~nm}$ wavelength. The quantities of Phosphomonoesterase enzyme 
calculated from the standard curve prepared with the known concentration of p-nitrophenol and expressed in $\mu \mathrm{g}$ p-nitrophenol $\mathrm{g}^{-1} \mathrm{~h}^{-1} \mathrm{using}$ the formula:

$\begin{array}{lc}\text { Phosphomonoesterase enzyme } & \mathrm{C} \times \mathrm{V} \\ \left(\mu \mathrm{g} \text { p-nitrophenol } \mathrm{g}^{-1} \mathrm{~h}^{-1}\right) & =---------- \\ & \text { Dwt } \times \mathrm{SW} \times \mathrm{t}\end{array}$

Where, $\mathrm{C}$ is the measured concentration of $\mathrm{p}$ Nitrophenol $(\mu \mathrm{g} / \mathrm{ml}$ filtrate), dwt is the dry weight of $1 \mathrm{~g}$ moist soil, $\mathrm{V}$ is the total volume of the soil suspension in milliliters, SW is the weight of soil sample used $(1 \mathrm{~g})$ and $t$ is the incubation time in hours. The data obtained were analysed through completely randomized design and two factorial completely randomized design. The significance of variance was determined by calculating the respective F-value and significance of specific means differences was determined by calculating the critical differences (C.D) at 5\% level of significance.

\section{Results and Discussion}

Mineral P-solubilization, ammonia production, Proteolytic activities and IAA production were examined from 10 Diazotrophic PGPR (P-Solubilizers, Psuedomonas, Azotobacter and Azospirillium) Qualitatively all the diazotrophic isolates were capable to produces ammonia (Table 1). 7 out of 10 test PGPR cultures were proteolytic producer with varied intensity where culture $\mathrm{P}$ 20 recorded highest proteolytic activity followed by P 03 (Table 1).

The diazotrophic proteolytic activator can act as exotoxin against phytopathogen by the action of protease enzyme. The selected Diazotrophic PGP cultures produces IAA ranged from 15.88 to $22.66 \mathrm{mg} \mathrm{l}^{-1}$. The culture P 03 produced the highest IAA (22.66 $\mathrm{mgl}^{-1}$ ) which was significant followed by culture $\mathrm{P}$ $20\left(22.57 \mathrm{mgl}^{-1}\right)$ which was at par with culture
$\mathrm{P}$ 03. The lowest IAA production was recorded with $\mathrm{P} 45\left(15.88 \mathrm{mgl}^{-1}\right.$ ) (Table 1). Thus, culture $\mathrm{P} 20$ and $\mathrm{P} 03$ was significant producer of IAA (Shrivastava et al., 2014; Gururani et al., 2014). The selected diazotrophic PGPR showed 60 to 100 percent seed germination ranged over control on wheat, rice, and maize seeds using water agar medium (Table 2). 100 per cent germination of wheat, rice and maize seeds recorded by $\begin{array}{llllll}\text { culture P } 20 \text { (Azospirillium) and P } 44 & 4\end{array}$ (Azotobacter). Result revealed that due to production of phytohormone (IAA) and mineral nutrient as shown in diazotrophic PGPR exhibit the highest seed germination.

Analysis of variance (Table 2), the diazotrophic PGP cultures, P 49 recorded significantly the highest P-solubilization at 7 days $(2.383 \%), 15$ days $(2.866 \%)$ and even at 30 days $(3.173 \%)$. On the contrary, culture $\mathrm{P}$ 28 recorded lowest per cent solubilization at 7 and 15 days. The results (Table 2) showed variation among the test cultures in solubilizing phosphate with days of incubation. The interaction effect of $\mathrm{pH}$ with days of incubation was found significant as days of incubation increase with corresponding decrease in $\mathrm{pH}$. Table 2 showed that mean decrease in $\mathrm{pH}$ ranged from 6.57 (at 0 days) to 4.01 (at 15 days) and thereafter, the $\mathrm{pH}$ raised to 5.24 at 30 days. The results clearly showed the relationship of $\mathrm{P}$ solubilization with decrease in $\mathrm{pH}$, which indicated that, a role of organic acid secretion by microbes to solubilizes insoluble phosphate of TCP with days of incubation.

On pot culture evaluation (Table 3 and 4), culture P20 showed superiority on enhancing biological growth character in brinjal which was evident from the data of root length, shoot length, plant height, root dry weight, shoot dry weight etc all increased due to inoculation treatment. 
Table.1 PGP activities produced by diazotrophic PGPR cultures

\begin{tabular}{|c|c|c|c|c|c|c|c|}
\hline \multirow[t]{2}{*}{ Sl. No. } & \multirow[t]{2}{*}{ Isolates } & \multicolumn{3}{|c|}{ Germination Percentage (\%) } & \multirow{2}{*}{$\begin{array}{l}\text { Ammonia } \\
\text { Production }\end{array}$} & \multirow{2}{*}{$\begin{array}{l}\text { Proteolytic activity } \\
\text { Diameter of clear } \\
\text { halo zone }(\mathrm{mm})\end{array}$} & \multirow[t]{2}{*}{ IAA $\left(\mathrm{mgl}^{-1}\right)$} \\
\hline & & Wheat & Maize & Rice & & & \\
\hline 1 & P 03 (Azospirillium) & 100 & 80 & 100 & + & 21 & 22.66 \\
\hline 2 & P 20 (Azospirillium) & 100 & 100 & 100 & + & 22 & 22.57 \\
\hline 3 & P 27 (Azotobacter) & 80 & 80 & 100 & + & 20 & 18.68 \\
\hline 4 & P 28 (Azospirillium) & 60 & 100 & 80 & + & - & 19.76 \\
\hline 5 & P 44 (Psuedomonas) & 100 & 100 & 100 & + & 17 & 21.34 \\
\hline 6 & P 45 (PSB) & 86.66 & 60 & 60 & + & - & 15.88 \\
\hline 7 & P 49 (PSB) & 80 & 80 & 100 & + & 20 & 20.45 \\
\hline 8 & P 50 (PSB) & 80 & 80 & 80 & + & 18 & 19.06 \\
\hline 9 & P 51 (PSB) & 60 & 100 & 100 & + & - & 18.83 \\
\hline 10 & P 53 (PSB) & 60 & 60 & 80 & + & 16 & 17.65 \\
\hline 11 & Control & 53.33 & 60 & 60 & & - & 4.13 \\
\hline & & & & & & S.ED ( $( \pm)$ & 0.375 \\
\hline & & & & & & C.Do.05 & 0.777 \\
\hline
\end{tabular}


Table.2 Effect of diazotrophic PGP cultures on P-solubilization (\%) as affected by days of incubation and Change in $\mathrm{pH}$ corresponding to its days of incubation

\begin{tabular}{|c|c|c|c|c|c|c|c|c|c|c|}
\hline \multirow[t]{2}{*}{ Isolates } & \multicolumn{4}{|c|}{$\begin{array}{cc}\text { P-solubilization (\%) with days of } \\
\text { incubation } \\
\begin{array}{l}\text { Change in pH with days of } \\
\text { incubation }\end{array}\end{array}$} & \multirow[t]{2}{*}{ Mean } & \multicolumn{4}{|c|}{ Change in $\mathrm{pH}$ with days of incubation } & \multirow[t]{2}{*}{ Mean } \\
\hline & 0 Days & 7 Days & 15 Days & 30 Days & & 0 Days & 7 Days & 15 Days & 30 Days & \\
\hline Control & 0.301 & 0.306 & 0.303 & 0.340 & 0.312 & 6.647 & 6.617 & 6.641 & 6.665 & 6.642 \\
\hline $\begin{array}{l}\text { P } 03 \\
\text { (Azospirillium) }\end{array}$ & 0.377 & 2.040 & 2.475 & 2.718 & 1.903 & 6.650 & 4.535 & 3.968 & 5.091 & 5.061 \\
\hline $\begin{array}{l}\text { P } 20 \\
\text { (Azospirillium) }\end{array}$ & 0.365 & 2.180 & 2.654 & 2.996 & 2.049 & 6.685 & 4.544 & 3.544 & 4.932 & 4.926 \\
\hline $\begin{array}{l}\text { P } 27 \\
\text { (Azotobacter) }\end{array}$ & 0.372 & 1.548 & 2.148 & 2.401 & 1.617 & 6.692 & 4.538 & 4.004 & 5.194 & 5.107 \\
\hline $\begin{array}{l}\text { P } 28 \\
\text { (Azospirillium) }\end{array}$ & 0.384 & 0.931 & 1.734 & 2.634 & 1.421 & 6.654 & 4.945 & 4.445 & 5.516 & 5.390 \\
\hline $\begin{array}{l}\text { P } 44 \\
\text { (Psuedomonas) }\end{array}$ & 0.349 & 2.095 & 2.434 & 2.672 & 1.888 & 6.490 & 4.394 & 3.827 & 5.341 & 5.013 \\
\hline P 45 (PSB) & 0.350 & 2.034 & 2.436 & 2.796 & 1.904 & 6.528 & 4.471 & 3.637 & 5.232 & 4.967 \\
\hline P 49 (PSB) & 0.383 & 2.383 & 2.866 & 3.173 & 2.201 & 6.658 & 4.382 & 3.315 & 4.541 & 4.724 \\
\hline P 50 (PSB) & 0.375 & 2.079 & 2.376 & 2.932 & 1.940 & 6.437 & 4.464 & 3.564 & 4.995 & 4.865 \\
\hline P 51 (PSB) & 0.373 & 1.772 & 2.338 & 2.893 & 1.844 & 6.452 & 4.488 & 3.588 & 4.992 & 4.880 \\
\hline P 53 (PSB) & 0.347 & 1.834 & 2.600 & 2.873 & 1.914 & 6.433 & 4.485 & 3.585 & 5.136 & 4.910 \\
\hline Mean & 0.361 & 1.746 & 2.215 & 2.584 & & 6.575 & 4.715 & 4.011 & 5.240 & \\
\hline & & \multicolumn{2}{|c|}{ S.ed $( \pm)$} & \multicolumn{2}{|c|}{$\mathrm{CD}_{0.05}$} & & & S.ed $( \pm)$ & \multicolumn{2}{|c|}{$\mathrm{CD}_{0.05}$} \\
\hline \multicolumn{2}{|l|}{ Cultures } & \multicolumn{2}{|c|}{0.012} & \multicolumn{2}{|c|}{0.025} & \multicolumn{2}{|c|}{$\mathrm{pH}$} & 0.031 & \multicolumn{2}{|c|}{0.061} \\
\hline \multicolumn{2}{|l|}{ Days } & \multicolumn{2}{|c|}{0.004} & \multicolumn{2}{|c|}{0.009} & \multicolumn{2}{|c|}{ Days } & 0.011 & \multicolumn{2}{|c|}{0.022} \\
\hline \multicolumn{2}{|c|}{ Interaction (Cultures×days) } & \multicolumn{2}{|c|}{0.051} & \multicolumn{2}{|c|}{0.101} & \multicolumn{2}{|c|}{ Interaction $(\mathrm{pH} \times$ days $)$} & 0.124 & \multicolumn{2}{|c|}{0.247} \\
\hline
\end{tabular}


Table.3 Effect of diazotrophic bacterial inoculation on Root Shoot ratio of Brinjal

\begin{tabular}{|c|c|c|c|c|c|c|c|c|}
\hline Treatments & $\begin{array}{c}\text { Root dry } \\
\text { weight (g) }\end{array}$ & $\begin{array}{c}\% \text { increase } \\
\text { over } \\
\text { control }\end{array}$ & $\begin{array}{l}\text { Shoot dry } \\
\text { weight } \\
\text { (g) }\end{array}$ & $\begin{array}{l}\% \text { increase } \\
\text { over control }\end{array}$ & $\begin{array}{c}\text { Total } \\
\text { biomass (g) }\end{array}$ & $\begin{array}{c}\% \text { increase } \\
\text { over control }\end{array}$ & $\begin{array}{l}\text { Root shoot } \\
\text { ratio }\end{array}$ & $\begin{array}{l}\% \text { increase } \\
\text { over control }\end{array}$ \\
\hline $\begin{array}{l}T_{1}=\text { Uninoculated } \\
\text { control }\end{array}$ & 0.305 & - & 5.037 & - & 5.342 & - & 0.060 & 0.000 \\
\hline $\begin{array}{l}\mathbf{T}_{2}=\text { Standart } \\
(50: 50: 50)\end{array}$ & 0.524 & 71.991 & 8.167 & 62.129 & 8.691 & 62.692 & 0.064 & 6.215 \\
\hline$T_{3}=$ P $51($ PSB $)$ & 0.552 & 81.182 & 8.562 & 69.978 & 9.114 & 70.616 & 0.064 & 6.642 \\
\hline $\mathrm{T}_{4}=\mathrm{P} 50(\mathrm{PSB})$ & 0.523 & 71.772 & 8.158 & 61.951 & 8.681 & 62.511 & 0.064 & 6.135 \\
\hline $\mathrm{T}_{5}=\mathrm{P} 49(\mathrm{PSB})$ & 0.646 & 112.144 & 9.214 & 82.908 & 9.860 & 84.575 & 0.070 & 16.033 \\
\hline $\begin{array}{l}\mathbf{T}_{6}=\mathbf{P} 03 \\
(\text { Azospirillium) }\end{array}$ & 0.587 & 92.779 & 8.774 & 74.186 & 9.362 & 75.246 & 0.067 & 10.725 \\
\hline $\begin{array}{l}\mathbf{T}_{7}=\mathbf{P} 20 \\
\text { (Azospirillium) }\end{array}$ & 0.672 & 120.678 & 9.310 & 84.820 & 9.982 & 86.865 & 0.072 & 19.456 \\
\hline $\begin{array}{l}\mathbf{T}_{8}=\text { P } 27 \\
(\text { Azotobacter })\end{array}$ & 0.519 & 70.460 & 8.438 & 67.516 & 8.958 & 67.684 & 0.062 & 2.034 \\
\hline $\begin{array}{l}\mathrm{T}_{9}=\mathrm{P} 44 \\
\text { (Pseudomonas) }\end{array}$ & 0.588 & 92.998 & 8.752 & 73.743 & 9.340 & 74.841 & 0.067 & 11.064 \\
\hline S.Ed. ( \pm$)$ & \multicolumn{2}{|c|}{0.049} & \multicolumn{2}{|c|}{0.140} & \multicolumn{2}{|c|}{0.150} & \multicolumn{2}{|c|}{0.005} \\
\hline C.D $D_{0.05}$ & \multicolumn{2}{|c|}{0.104} & \multicolumn{2}{|c|}{0.295} & \multicolumn{2}{|c|}{0.316} & \multicolumn{2}{|c|}{0.012} \\
\hline
\end{tabular}


Table.4 Effect of diazotrophic bacterial inoculation on root length $(\mathrm{cm})$, shoot length $(\mathrm{cm})$, plant height $(\mathrm{cm})$ number of leaves and branches of brinjal

\begin{tabular}{|c|c|c|c|c|c|c|c|c|c|c|}
\hline Treatments & $\begin{array}{c}\text { Root } \\
\text { length } \\
(\mathrm{cm})\end{array}$ & $\begin{array}{c}\text { Percent } \\
\text { increase } \\
\text { over } \\
\text { control }\end{array}$ & $\begin{array}{c}\text { Shoot } \\
\text { length } \\
(\mathrm{cm})\end{array}$ & $\begin{array}{c}\text { Percent } \\
\text { increase } \\
\text { over } \\
\text { control }\end{array}$ & $\begin{array}{c}\text { Plant } \\
\text { height } \\
(\mathrm{cm})\end{array}$ & $\begin{array}{c}\text { Percent } \\
\text { increase } \\
\text { over } \\
\text { control }\end{array}$ & $\begin{array}{l}\text { Number } \\
\text { of } \\
\text { branches }\end{array}$ & $\begin{array}{c}\% \\
\text { increase } \\
\text { over } \\
\text { control }\end{array}$ & $\begin{array}{l}\text { Number } \\
\text { of leaves }\end{array}$ & $\begin{array}{c}\% \\
\text { increase } \\
\text { over } \\
\text { control }\end{array}$ \\
\hline $\begin{array}{l}T_{1}=\text { Uninoculated } \\
\text { control }\end{array}$ & 6.93 & 0 & 25.01 & 0 & 31.95 & 0 & 1.333 & - & 6 & - \\
\hline $\begin{array}{l}T_{2}=\text { Standart } \\
(50: 50: 50)\end{array}$ & 8.00 & 15.38 & 34.37 & 37.39 & 42.37 & 32.62 & 3.000 & 125 & 10.667 & 77.778 \\
\hline $\mathrm{T}_{3}=\mathrm{P} 51(\mathrm{PSB})$ & 8.30 & 19.71 & 35.73 & 42.86 & 44.03 & 37.83 & 3.333 & 150 & 11.000 & 83.333 \\
\hline $\mathrm{T}_{4}=\mathrm{P} 50(\mathrm{PSB})$ & 7.80 & 12.50 & 34.50 & 37.93 & 42.30 & 32.41 & 3.000 & 125 & 10.333 & 72.222 \\
\hline $\mathrm{T}_{5}=\mathrm{P} 49(\mathrm{PSB})$ & 8.37 & 20.67 & 36.53 & 46.06 & 44.90 & 40.55 & 3.667 & 175 & 14.333 & 138.889 \\
\hline $\begin{array}{l}\mathrm{T}_{6}=\mathrm{P} 03 \\
(\text { Azospirillium) }\end{array}$ & 8.27 & 19.23 & 35.17 & 40.59 & 43.43 & 35.96 & 3.333 & 150 & 13.667 & 127.778 \\
\hline $\begin{array}{l}\mathbf{T}_{7}=\mathbf{P} 20 \\
\text { (Azospirillium) }\end{array}$ & 8.43 & 21.63 & 36.50 & 45.92 & 44.93 & 40.65 & 4.000 & 200 & 14.667 & 144.444 \\
\hline $\begin{array}{l}\mathbf{T}_{8}=\mathrm{P} 27 \\
\text { (Azotobacter) }\end{array}$ & 7.97 & 14.90 & 33.39 & 33.48 & 41.35 & 29.44 & 2.667 & 100 & 10.000 & 66.667 \\
\hline $\begin{array}{l}\mathrm{T}_{9}=\text { P } 44 \\
\text { (Pseudomonas) }\end{array}$ & 8.33 & 20.19 & 35.34 & 41.28 & 43.67 & 36.71 & 3.667 & 175 & 13.000 & 116.667 \\
\hline S.Ed. $( \pm)$ & \multicolumn{2}{|c|}{0.124} & \multicolumn{2}{|c|}{0.299} & \multicolumn{2}{|c|}{0.269} & \multicolumn{2}{|c|}{0.384} & \multicolumn{2}{|c|}{0.351} \\
\hline C. $D_{0.05}$ & \multicolumn{2}{|c|}{0.262} & \multicolumn{2}{|c|}{0.628} & \multicolumn{2}{|c|}{0.565} & \multicolumn{2}{|c|}{0.966} & \multicolumn{2}{|c|}{0.738} \\
\hline
\end{tabular}


Table.5 Population dynamics of total bacteria, PSB, Azospirillium, Azotobacter and Pseudomonas after harvest, DHA activity, Hydrolysis of fluorescein diacetate and Phosphomoesterase activity by diazotrophic PGPR

\begin{tabular}{|c|c|c|c|c|}
\hline Treatment detailed & CFU $\left(10^{6} \mathrm{ml}^{-1}\right)$ & $\begin{array}{c}\text { DHA Activity ( } \mu \mathrm{g} \\
\text { TPF } \mathrm{g}^{-1} \text { ) }\end{array}$ & $\begin{array}{c}\text { Hydrolysis of } \\
\text { fluoresin diacetate } \\
\left(\mu \mathrm{g} \mathrm{FDA} \mathrm{g}^{-1} \mathbf{h r}^{-1}\right)\end{array}$ & $\begin{array}{l}\text { Phosphomoesterase } \\
\text { activity }(\mu \mathrm{g} \mathrm{p}- \\
\left.\text { nitrophenol } \mathrm{g}^{-1} \mathbf{h}^{-1}\right)\end{array}$ \\
\hline $\mathbf{T}_{1}=$ Uninoculated control & 2.5 & 70.76 & 32.509 & 29.399 \\
\hline$T_{2}=$ Standard $(50: 50: 50)$ & 3.5 & 102.8 & 62.019 & 72.237 \\
\hline$T_{3}=P 51(P S B)$ & 2.1 & 109.24 & 64.193 & 86.738 \\
\hline $\mathrm{T}_{4}=\mathrm{P} 50(\mathrm{PSB})$ & 1.7 & 107.22 & 69.969 & 83.221 \\
\hline$T_{5}=P 49(P S B)$ & 3.1 & 125.83 & 75.125 & 94.231 \\
\hline $\mathbf{T}_{6}=\mathrm{P} 03($ Azospirillium $)$ & 2.8 & 120.84 & 79.265 & 77.090 \\
\hline $\mathrm{T}_{7}=\mathrm{P} 20$ (Azospirillium) & 3.3 & 140.40 & 80.495 & 91.152 \\
\hline $\mathrm{T}_{8}=\mathrm{P} 27$ (Azotobacter) & 3.0 & 116.38 & 73.561 & 75.040 \\
\hline $\mathrm{T}_{9}=$ P 44 (Pseudomonas $)$ & 2.0 & 112.50 & 64.249 & 86.595 \\
\hline S.Ed. $( \pm)$ & - & 0.355 & 0.277 & 0.195 \\
\hline $\mathrm{CD}_{0.05}$ & - & 0.746 & 0.582 & 0.410 \\
\hline
\end{tabular}


For instances, P 20 recorded highest per cent increased in root dry weight $(120.6 \%)$, shoot dry weight $(84.82 \%)$, total biomass $(86.86 \%)$, root shoot ratio $(19.45 \%)$, root length $(21.6 \%)$, plant height $(40.6 \%)$, no. of leaves $(144.4 \%)$ and no. of branches (200\%) over uninoculated control. Therefore, culture P 20 was regarded as superior PGP cultures in enhancing growth characters of brinjal followed by culture P49 (PSB).

The microbial colony was enumerated by using their respective media. Table 5 showed that overall bacterial population was recorded highest in standard treatment with $3.5 \mathrm{cfu}$ $10^{6} \mathrm{ml}^{-1}$. However, the highest established population of Azospirillium was recorded in $\mathrm{P}$ 20 (3.3 cfu $\left.10^{6} \mathrm{ml}^{-1}\right)$ followed by P 49 (3.1 cfu $10^{6} \mathrm{ml}^{-1}$ ) and P 27 (3.0 cfu $\left.10^{6} \mathrm{ml}^{-1}\right)$. Large bacterial population was detected in standard treatment indicating colonization by indigenous bacteria. These results the isolates were able to survive and colonize in the rhizospheric soil despite of competition by native microflora.

The dehydrogenase activity (DHA) is purely a microbiological origin, and represents the oxidoreduction process in the respiration process which is also a good indicator of soil microbiological activity (Singh and Singh, 2005). DHA was recorded significantly highest in all the inoculated treatment over control and ranged from 107.2 to $140.40 \mu \mathrm{g}$ TPF $\mathrm{g}^{-1}$ where P 20 recorded highest DHA and lowest in P 50 (Table 5). Thus, the diazotrophic bacterial cultures were capable in mineralizing fresh organic matter and humus relating to soil fertility. However, the value of DHA varied among the treatments because of diverse active microbial population abundance in the soil, effect of the substrate and soil condition.

Fluorescein diacetate is a membrane-bound enzymes such as esterases, proteases, and lipases, resulting in the release of fluorescein by soil microorganism and inhibited the deleterious microbes (Schnurer and Rosswall, 1982). FDA was recorded significantly highest in inoculated treatments over control ranging from 64.19 to
80.5 $\mu \mathrm{g}$ FDA $\mathrm{g}^{-1} \mathrm{hr}^{-1}$ where culture $\mathrm{P} 20$ recorded the highest FDA and the lowest FDA with P 50 (Table 5). The variation of FDA among the treatments was recorded because of diverse activity and density of the introduced PGPR associated with various non-specific enzyme such as esterases, proteases, and lipases. The above data could be reported that the selected isolates were capable of suppressing the growth of pathogen indirectly through proteases activity. Thus, the application of PGPR is a potential alternative approach in disease management.

P 49 (PSB) (Table 5) recorded significantly highest phosphomonoesterase activity $(94.23 \mu \mathrm{g}$ p-nitrophenol $\left.\mathrm{g}^{-1} \mathrm{~h}^{-1}\right)$ and lowest Phosphomonoesterase activity in P $27(75.04 \mu \mathrm{g}$ p-nitrophenol $\mathrm{g}^{-1} \mathrm{~h}^{-1}$ ) which clearly resulted that $\mathrm{P}$-solubilizer efficiently mineralized $\mathrm{P}$ by the action of phosphomonoesterase enzyme in soil organic matter and therefore promotes the dispersal and activity of phosphorus (Nannipieri et al., 2011).

The recent investigation, gives a clear picture about the role of diazotrophic bacteria on inoculating to Brinjal crop enhanced growth and development of the crop through direct and indirect PGP activities such as production of IAA, Ammonia, Mineral P-solubilization and proteolytic activity. Diazotrophic PGP were also capable to colonize and survived with various microbial enzyme activities such as Dehydrogenase, FDA and Phosphomonoestease. Thus, it can be concluded that the Diazotropic PGPR are the promising alternative biopesticides, biostimulator and biofertilizer.

\section{References}

Aahrafuzzaman, M., Hossen, F.A., Ismail, M.R., Hoque, A., Islam, M.Z., Shahidullah, S.M. and Meon, S. (2009). Efficiency of plant growth-promoting rhizobacteria (PGPR) for the enhancement of rice growth. African $J$. Biotechnol. 8(7): 1247-1252.

Gururani, M.A., Ji, S.H. and Chun, S.C. (2014). 
Isolation and characterization of plant growth promoting endophytic diazotrophic bacteria from Korean rice cultivars. Microbial Res. 169(1): 83-98.

Hassan, E.A., Naglaa, M. B., Ahmed, A. E., Nerhan, A. E. and Ramadan, E. M. (2017). Relationship between Ralstonia solanacearum and bioagents recovered from different habitats. Intern. J. Sci. Engg. Res. 8(1): 91-104.

Jackson, M.L. (1973). Soil Chemical Analysis. Prentice hall of India Pvt. Ltd., New Delhi.

Joseph, B., Patra, R.R. and Lawrence, R. (2007). Characterization of plant growth promoting Rhizobacteria associated with chickpea (Cicer arietinum L). Intern. J. Plant Prod.1:

Kennedy, I.R., Choudhury, A.T.M.A. and Kecskès, M.L. (2004). Non-symbiotic bacterial diazotrophs in crop-framing systems: can their potential for plant growth promotion be better exploited. Soil Biol. Biochem.36: 1229-1244.

Kumar, R. S., Ayyadurai, N., Pandiarajal, P., Reddy, A.V., Venkateswarlu, Y., Prakask, O. and Sakthivel, N.N. (2005). Characterization of antifungal metabolite producted by a new strain Pseudomonas aeruginosa $\mathrm{PUPa} 3$ that exhibits broad spectrum antifungal activities and fertilizing traits. J. Appld. Microbiol. 98: 145-154.

Nannipieri, P., Giagnoni, L., Landi, L. and Renella, G. (2011). Role of Phosphatase Enzymes in Soil, in Phosphorus in Action. In: Soil Biology. Bünemann, E. et al., (eds.). Springer, Berlin, Heidelberg, Vol. 26, pp. 215-243.

Ritu, S., Kapil, D. P., Ajay, K. and Monika, S. (2017). PGPR Isolates from the Rhizosphere of Vegetable Crop Momordica charantia: Characterization and Application as Biofertilizer. Intern. J. Curr. Microbiol. App. Sci. 6(3): 1789-1802.

Sakthi, S. S., Saranraj, P. and Sivasakthivelan, P. (2013). Prevalence and Production of Plant Growth Promoting Substance by Pseudomonas fluorescens Isolates from Paddy Rhizosphere Soil of Cuddalore District, Tamil Nadu. African J. Basic Appl. Sci. 5(2): 95-101.

Schnurer, J. and Rosswall, T. (1982). Fluorescein Diacetate Hydrolysis as a Measure of Total Microbial Activity in Soil and Litter. Appl. Environ. Microbiol. 43(6): 1256-1261.

Shrivastava, A. K., Khilendra, D. and Shrivastava, D.K. (2014). Plant growth promoting rhizobacterial strains from rice rhizospheric soil. Intern. J. Curr. Microbiol. App. Sci. 3(4): 774-779.

Singh, J. and Singh, D.K. (2005). Dehydrogenase and phosphomo- noesterase activities in groundnut (Arachis hypogaea L.) field after diazinon, imidacloprid and lindane treatments. Chemo-sphere 60: 32-42.

Somasegaren, P. and Hoben, H.J. (1994). Hand book for rhizobia. Methods in legumes Rhizobium technology. Spinger Verlag, New York, pp. 1-441.

Tabatabai, M.A. and Bremner, J.M. (1969). Use of p-nitrophenyl phosphate for assay of soil phosphatase activity. Soil Biol. Biochem. 1: 301-307.

Thalman, A. (1968). Estimation of microbial activities by K. Alef. Chapter 5, pp. 228230.

Wohler, I. (1997). Auxins-indole derivatives in soil determined by a colorimeter method and by high performance liquid chromatography, New York. Microbial. Res. 152(4): 399-405.

\section{How to cite this article:}

Rasinja Englengpi, Rajen Baruah and Amrita Phukan. 2019. Screening and Interactive Effects of Soil Microbial Enzymes Activities of Diazotrophic PGPR. Int.J.Curr.Microbiol.App.Sci. 8(08): 346-357. doi: https://doi.org/10.20546/ijcmas.2019.808.039 